\title{
Challenges Contributing to Poor Integration of Educational Technology at Some Schools in South Africa
}

Moses Makgato

Tshwane University of Technology ,Department of Educational Studies

\section{Doi:10.5901/mjss.2014.v5n20p1285}

\begin{abstract}
Information and communication technology (ICT) has the potential of enhancing teaching and learning activities in schools and higher education. Numerous studies demonstrated the potential positive impact of ICTs in teaching and learning, but schools still have challenges in fully integrating ICT in the teaching and learning. The purpose of this study was to investigate the extent of integrating ICT in their teaching and learning and challenges the schools have in implementing the e-learning strategies at their schools. The participants of this study were six public schools around Pretoria, Gauteng Province in South Africa. Twenty four teachers from 6 secondary public schools who were conveniently selected took part in the study. Data collection instruments included questionnaires and interviews. The findings included poor usage of computers such power-point, wordprocessing, emails, printing, data storage in both teachers. Teachers did not receive professional computer literacy and training. There should be enough computers at schools, even there are other invention such as delivery of tables in order to supplement each other. There should be regular computer literacy and training for teachers, which also focus on instilling in teachers the interest and relevant philosophy and belief in using ICT in the school curricular.
\end{abstract}

Keywords: educational technology, challenges, schools, ICT, computer literacy

\section{Introduction}

Information and communication technology (ICT) has the potential of enhancing teaching and learning activities in schools and higher education. ICTs have been widely used with the impression that they can enhance innovative ways of teaching and learning. Numerous studies demonstrate the potential positive impact of ICTs in teaching and learning (Mayisela, 2014). For instance, a study conducted in Australia on the impact of ICTs on teaching and learning confirms that ICTs enhance investigating reality and building knowledge, active learning and authentic assessment; engage students by motivation and challenge; provide tools to increase student productivity; provide scaffolding to support higher level thinking; increase learner independence, collaborative and cooperative learning; allow tailoring of learning to the learner; and overcome physical disabilities (Newhouse 2002). Information and Communications Technologies (ICT) are increasingly used in schools to support teaching and learning based on the belief that this will improve teaching and learning outcomes (Becta, 2006). However, Newhouse and Clarkson (2008) argues that this is unjustified and that it depends on how the educational technology is used rather than that it is used (Lei \& Zhao, 2007). Wozney, Venkatesh \& Abrami (2006) contended that increased availability of computers at schools might not be sufficient to promote their usage in classroom. In a survey of 4,083 teachers, Becker et al. (1999) noted that only $5 \%$ of upper-elementary, $4 \%$ of middle grade and $13 \%$ of high-school teachers were currently integrating computers in the classroom, despite increased availability. Another study by Cuban et al. (2001) provided further evidence that increased access to computers and related resources does not necessarily lead to classroom use. Information and Communication Technology (ICT) is widely used in education for collection, management, and analysis. ICT in education includes a variety of tools, such as computers, video clips, powerpoint presentation, simulation, word processors, image graphic software, email, and Internet, WebCT. ICT use can influence teaching and learning styles by changing the emphasis from a teacher-centered to a learner-centered style and provides opportunities to improve information-reasoning skills, communication skills, higher thinking skills, creativity, and problem solving (Shaikh \& Khoja, 2011; Yusuf \& Afolabi, 2010). The purpose of this study was to investigate the current barriers related to the use of ICT (computers) into the teaching and learning of curriculum at some schools in Gauteng province, South Africa, 


\section{Literature Review}

\subsection{Factors contributing negatively on the use of JCT in teaching}

From past studies (Hew \& Brush, 2007) several barriers were found and can be classified into six main categories: (a) resources, (b) knowledge and skills, (c) institution, (d) attitudes and beliefs, (e) assessment, and (f) subject culture. These barriers are listed in order of the relative frequency in which they were mentioned in the studies reviewed (see

\subsection{Lack of educator confidence in the use of Information and communication Technology}

Several studies suggest that one of the challenges that forbid educators from using ICT in their teaching is the lack of confidence; Dawes (2001) considers this as a contextual factor which can act as a challenge. According to Becta (2004) much of the research suggests that this is a major challenge to consumption of ICT by educators in the classroom. Beggs (2000) maintained that educators 'fear of failure' caused a lack of confidence. On the other hand Balanskat (2006) debates that limitation in educators' ICT knowledge makes them feel anxious about using these in the classroom and thus not confident to use it in their teaching. In light of the above, the researcher engaged educators in their daily use of ICT equipment during teaching in primary school classrooms;

\subsection{Lack of educator competence in the use of Information and communication Technology}

Another challenge which is directly linked to educator's confidence is educators' competence in the use of Information and Communication Technology into pedagogical practice. Newman (2006) found that many educators missed the knowledge and skills to use Information and Communication Technologies and were not passionate about the changes and integration of supplementary learning linked with bringing Information and Communication Technologies into their teaching practice. Current research has demonstrated that the level of this challenge differs from one country to another country. In the developing countries, research reported that educators' lack of technological competence is a main challenge to their acceptance and adoption of Information and Communication Technology (Pelgrum (2001), Al-Oteawi (2002) In Syria for example educators lack of technological competence has been mentioned as the main challenge.

\subsection{Lack of technical support in the use of Information and communication Technology}

According to Sicilia (2005) technical problems were found to be a major challenge for educators in using ICT in teaching and learning. These technical challenges included waiting for websites to open, failing to connect to the internet, printers not printing, malfunctioning computers, technical challenges hindered the smooth flow of the classroom activity Sicilia (2005), Korte \& Husing (2007) argued that Information and Communication Technology back or maintenance contracts in schools help educators to use Information and Communication Technology in teaching without losing time through having to prepare software and hardware problems.

\subsection{Lack of effective training in the use of Information and communication Technology}

The challenges most often referred to in most literatures is lack of effective training (Albirini, 2006). One finding of Pelgrum (2001) study was that there were not enough training opportunities for educators in the use of Information and Communication Technology in the classroom environment. Ozden (2007) and Toprakci (2006) found that one of the main challenge with the use of new Information and Communication Technology is limited educator training in the According to Becta (2004) the issue of training is certainly complex because it is important to consider several components to ensure the effectiveness of the training. These were time for training, pedagogical training, skills training, and ICT use in initial educator training. Correspondingly, recent research by Gomes (2005) relating to science education concluded that lack of training in digital literacy, lack of pedagogic and didactic training in how to use ICT in the classroom, and lack of training pertaining to the use of technologies in science specific areas were obstacles to using new technologies in classroom practice. Some of the Saudi Arabian studies reported similar reasons for failure in using educational technologies, the weakness of educator training in the use of computers, the use of a "delivery" teaching style instead of investment in modern technology.

In order to meet the demand for pedagogical training, it is imperative to train educators in specific Information and Communication Technology skills (Becta, 2004). Schoepp (2005) claims that when new technologies is to be integrated 
in the classroom, educators have to be trained in the use of these particular technologies. According to Newhouse 2002) initial training is needed for educators to develop appropriate skills, knowledge, and attitudes regarding the effective use of computers to effectively meet the didactic needs in the classroom. Newhouse (2002) argues that this also requires persistence provision of professional development to preserve appropriate skills and knowledge.

Basically, when there are new tools and approaches to teaching, educator training is necessary. According to Balanskat (2006) inadequate or inappropriate training results in educators being not sufficiently confident to carry out full integration of Information and Communication Technology in the classroom. Newhouse (2002) submits that "educators need not only be computer literate but they also need to develop skills in integrating computer use into their teaching and earning programmes.

According to Newhouse ( 2005) educators need training in educational technology support for teaching in the classroom. Similarly Sicilia (2005) discovered that educators want to learn how to use new technologies in the classroom but the lack of opportunities for professional development obscured them from integrating technology in certain subjects. Other debatable issues related to professional development programmes in Information and Communication Technology are outdated and not meet the specific training and learning needs of educators and are not regularly updated.

\subsection{Resistance to change and negative attitudes in the use of Information and communication technology}

Much research into the challenges to the use of ICT into education found that educators' attitudes and an inbuilt resistance to change were predominant (Cox \& Cox, 1999).From the depth psychology of questionnaire, Gomes (2005) found that science educator's resistance to change concerning the use of new strategies is an obstruction to ICT utilization in science teaching. According to Empirica (2006) educators who are not using new technology such as computes in their classroom are still of the belief that the use of ICT has no gains or unclear benefits. Resistance to change is an indication that something is incorrect professional development of teachers with regard to the philosophy and belief of the programmes.

\subsection{Lack of time in the use of Information and communication Technology}

Several studies suggest that many educators have competence and confidence in using Information and Communication Technology instruments in the classroom, but they still make little use of technologies because they do not have enough time. Time limitations in using computers in the classrooms is the problem teachers are experiencing ( Mumtaz,2006) . Agreeing with Sicilia (2005) the most common challenge described by all educators was the lack of time they had to plan technology integration in lessons presentation, in searching the internet websites, or look for simulations in YouTube related to the theme of their lessons.

\subsection{Lack of personal access for educators in the use of Information and communication Technology}

Talking about the issue of access to resources, it is important not only to imagine the access educators need in order to teach with Information and Communication Technology, but also to look at the need for educators to have their own personal access to Information and Communication Technology, to allow them to design and develop lessons, for example.

One of the components which contribute to the level of an educator's confidence in using ICT in school is the amount of personal access to Information and Communication Technology by the teacher ( Ross 2000). Perhaps unsurprisingly, those educators in their view who made little or no personal use of ICT had a low level of confidence in using it in their lessons. Ross (2000) also found this relationship. Educators who use ICT regularly are confident in using it and have a positive attitude towards it, perceiving it as a useful instrument in both their personal and their teaching work (Guha 2000). In a study by Guha (2000) in an interview one of responses from educators confirm, "...initially there was a lot of phobia, now that educators have computers at home they have less fear in using them.

\section{Research Methodology}

The participants of study were six public schools around Pretoria, Gauteng Province in South Africa. These participants were conveniently selected in order to investigate the extent of integrating ICT in their teaching and learning and challenges the schools have in implementing the e-learning strategies at their schools. Twenty four teachers from 6 secondary public schools who were conveniently selected took part in the study. Questionnaire and semi-structured 
interviews were used to collect data from teachers.

\section{Findings and Discussions}

\subsection{Teachers questionnaire data}

The teachers were asked to verify their teaching experiences. Table 1 below shows their responses:

Table 1: Distribution of Teachers' Teaching Experience

\begin{tabular}{|l|c|c|}
\hline Teaching experience (years) & Frequency & Percent \\
\hline less than 2 & 2 & $8 \%$ \\
\hline between 2 and 3 & 0 & $0 \%$ \\
\hline between 4 and 5 & 0 & $0 \%$ \\
\hline between 6 and 10 & 4 & $17 \%$ \\
\hline more than 10 & 18 & $75 \%$ \\
\hline Total & 24 & $100 \%$ \\
\hline
\end{tabular}

Table 1 shows that 2(8\%) of the teacher participants have less than 2years of teaching experience; no teachers have teaching experience between 2 and 5 years; 4(17\%) have teaching experience between 6 and 10 years and 18(75\%) of the teachers have more than 10 years of teaching experience. Although the results of this study cannot significantly correlate experience and use of technology in teaching it is known that some experience teachers from previous regime, particularly in our country, teachers who used to teachers-centeredness method are reluctant to use modern technologies to teach (Makgato, 2012).

Figure 1: Teachers ability to distribute email

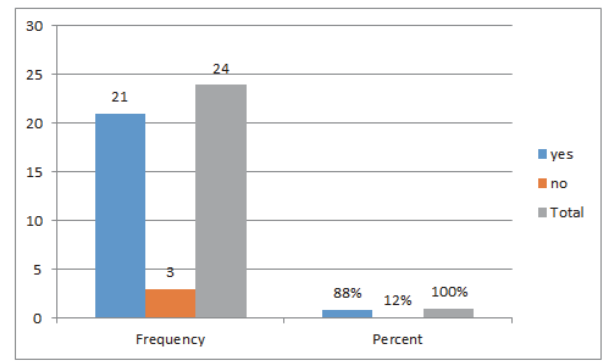

Figure 1 shows that $21(88 \%)$ of the 24 teachers have the skill to use e-mail and only $3(12 \%)$ cannot use this tool. These findings are supported by the literature by Jhurree (2005) who states that technology offers amongst other benefits, a communication platform; in the not so distant past, geographical distance was a major hurdle when it came to communicating with people around the world, technology has changed that, through networks and the Internet, it is now possible to communicate with anyone in the world. Technology has also presented schools with an excellent medium to share ideas and experiences with students, teachers, and administrators and communicate, exchange knowledge and concerns, meet experts and peers, and share work in collaborative projects.

Table 2: Teachers ability to use MS-Excel spreadsheets

\begin{tabular}{|c|c|c|}
\hline & Population (N)=24 \\
\hline Response & Frequency & Percent \\
\hline Yes & 21 & $88 \%$ \\
\hline No & 3 & $12 \%$ \\
\hline Total & 24 & $100 \%$ \\
\hline
\end{tabular}


Table 2 shows that $21(88 \%)$ of the 24 teachers who participated in the study indicated that they can use MS-Excel spreadsheets whilst 3(12\%) cannot use this program. As maintained by Jhurree (2005) that teachers can use this tool for student record keeping, lesson planning, preparing handouts, tutorials and slides, preparing exams papers, marking papers and recording of results, performing some type of analyses statistical on marks. In so doing, a lot of time that could be wasted in compiling administrative work manually or traditionally is saved.

Table 3: Teachers ability to use power-point presentation

\begin{tabular}{|c|c|c|}
\hline \multicolumn{3}{|c|}{ Population (N)=24 } \\
\hline Response & Frequency & Percent \\
\hline Yes & 20 & $83 \%$ \\
\hline No & 4 & $17 \%$ \\
\hline Total & 24 & $100 \%$ \\
\hline
\end{tabular}

Table 3 shows that 20(83\%) of the 24 teachers have the skill to use Power-Point presentation whilst only 4(17\%) cannot use this tool. This indicates that most of the teachers are motivated to create an enhanced learning environment for learners, through the use of slides and presentations rather than the traditional use of chalk, talk and textbook to teach. The use of this tool can be motivating to both teachers and learners, (Jhurree 2005).

Table 4: Ability of teachers to store data on a USB

\begin{tabular}{|c|c|c|}
\hline \multicolumn{3}{|c|}{ Population (N) $=24$} \\
\hline Response & Frequency & Percent \\
\hline yes & 21 & $88 \%$ \\
\hline no & 3 & $12 \%$ \\
\hline Total & 24 & $100 \%$ \\
\hline
\end{tabular}

Table 4 indicates that $21(88 \%)$ have the skill to store information on USBs whilst only $3(12 \%)$ of the 24 teacher participants indicated that they don't have the skill. This indicate that most teachers are already moving towards effective ICT integration with teaching, although there are some who still need to be equipped with this skill. The use of such ICT tools can supplement teachers' instruction (Jhurree ,2005). The use of CDs and USBs can save a lot of time on writing text by hand on the chalkboard. Copies of documents can now be easily distributed and these tools are convenient for enhancing knowledge sharing. Moreover, instruction is made easier, and motivating for all, as slides and presentations saved on these tools can be shared at anytime and anywhere through power-point software.

Table 5: Ability of teachers to use printing

\begin{tabular}{|c|c|c|}
\hline \multicolumn{3}{|c|}{ Population (N) $=24$} \\
\hline Response & Frequency & Percent \\
\hline yes & 20 & $83 \%$ \\
\hline no & 4 & $17 \%$ \\
\hline Total & 24 & $100 \%$ \\
\hline
\end{tabular}

Table 5 shows that most 20(83\%) of the 24 teacher participants have the skill to print and 4(17\%) do not have this skill. As argued by Jhurree (2005), printing is a powerful administrative tool for teachers. These responses imply that most teachers can plan, prepare handouts, tutorials, examination papers, compile records of marks and print them out in a more user-friendly way than tedious manual methods that were used before the ICT integration with teaching and learning activities.

Table 6: Teachers ability to use data projector

\begin{tabular}{|c|c|c|}
\hline \multicolumn{2}{|c|}{ Population (N) $=24$} \\
\hline Response & Frequency & Percent \\
\hline yes & 18 & $75 \%$ \\
\hline no & 6 & $25 \%$ \\
\hline Total & 24 & $100 \%$ \\
\hline
\end{tabular}


Table 6 illustrates that $18(75 \%)$ of the teacher participants have the skill to use data projectors and $6(25 \%)$ indicated that they don't have the skill of using data projector. These responses indicate that most teachers are now in a position to share knowledge through the use of these powerful tools. This is supported by Kozma (2005) who asserts that data projector used to improve the delivery of and efficiency by which instruction is distributed.

\subsection{Interview data}

Interview data from teachers were analysed by recordings, transcribed and categorised into themes, according to the patterns of the transcripts. One of the theme emerged from the interviews is discussed below.

\subsubsection{ICT integration with Teaching and Learning}

The responses that were given under this theme gave a clear indication of the present teachers' pedagogical practices in relation to ICT usage, in terms of moving away from teacher-centered classroom practices to learner-centered ones. Although the teachers are aware of the need to keep abreast with the rest of the information society, they indicated their interests to use ICTs in their teaching but with an emphasis on obstacles hindering this integration. The verbatim responses from teachers in different schools within this theme are stated below:

Teacher from School A:

Definitely using tools such as Gauteng on Line would give both the learners and the teachers an opportunity to research and access more educational information; but there is no timetable for the teachers and learners to follow in terms of ICT access, making it almost impossible to integrate the teaching an learning activities with ICTs.

\section{Teacher from School B:}

All subjects can be taught better with ICT training. Thousands of lessons; practical investigations and academic articles relevant for all subjects are available online. However, the government has given classrooms without chairs and textbooks; so what can you expect on projections and laptops?

Teacher from School C:

Individual teachers have to find their way to get access to ICTs, which is a difficult process as the computer lab is locked always, some ICT equipment are not in good condition.

Teacher from School D:

ICTs have a very positive impact on teaching and learning as more educational information is available through the internet, however, more time to familiarize with these tools is still required.

\section{Teacher from School E:}

There has been remarkable improvement in terms of marks and presentation of assignment and projects due to use of ICTs particularly computers. However, most learners with these skills have learnt to use them outside the school as computer literacy is not on the time-table.

\section{Teacher from School F:}

Integration is almost impossible due to a very small number of computers which are usually offline; being available for large numbers of learners and teachers.

These views have also been echoed by Balanskat et al (2006) who assert that that the inability of teachers and students to access ICT resources is a result of a number of other factors and not only the lack of ICT infrastructure. Sometimes a school may have a high quality of ICT resources but these are inappropriately organized and thus not optimally used. In some schools for instance, prior booking of the ICT classroom is required, or internal school network cannot be accessed from outside. As a result teachers and students do not have the opportunity to use ICT at any time according to their needs. Sicilia (2005) also noted that in some cases teachers complained that computers had to be 
booked in advance and teachers would forget to do so, or they could not book them for several periods in a row when they wanted to work on several projects with their students. This aspect reveals that lack of access to ICTs is a serious constraint, barrier or challenge to achieving desired ICT competencies that may enhance teaching and learning

\section{Conclusion}

This study revealed that teachers at the six still have some challenges in integrating ICT in teaching and learning. There were about 4 (teachers) out of 24 who indicated that they cannot use Power-Point presentation, and this may not be a significant number, given the small scale of the participants. The study also found that only 4 teachers indicated that they cannot use printing, and this may be critical in that learners may not receive full service of teaching and learning from those teachers. Most of the teachers (79\%) indicated that they did not receive professional training in ICT, which may affect their interest and the ability to use ICT in the classroom. Although the study did not measure in details all the aspect related to the integration of ICT in the classroom, it managed to share information on some of barriers that can still be attended to in order to have a full integration of ICT in classrooms. There should be enough computers at schools, even there are other invention such as delivery of tables in order to supplement each other. There should be regular computer literacy and training for teachers, which also focus on instilling in teachers the interest and relevant philosophy and belief in using ICT in the school curricular.

\section{References}

Albirini, A. (2006). Teachers' attitudes toward information and communication technologies: The case of Syrian EFL teachers. Computers and Education, 47, 373-398.

Al-Oteawi, S.M. (2002). The perception of administrators and teachers in utilizing information technology in instruction, administrative work, technology planning and staff development in Saudi Arabia. Doctoral dissertation, Ohio University, Ohio. p36

Beggs, T.A. (2000). Influence and barriers to adoption of instructional technology. Paper presented at the Proceedings of the Mid-South Instructional Technology Conference, Murfreesboro, TN. p9-11

Balanskat, A., Blamire, R. \& Kefala, S. (2006). A review of studies of ICT impact on schools in Europe, European Schoolnet: European Communities.

Becta. (2006). The Becta Review 2006: Evidence on the progress of ICT in education. Becta ICT Research.

Becker, H. J., Ravitz, J. L., \& Wong, Y. (1999). Teacher and teacher-directed student use of computers and software (Rep. No. 3). Irvine: Center for Research on Information Technology and Organizations, University of California, Irvine; University of Minnesota, Center for Research on Information Technology and Organizations.

Cox, M., Preston, C., Cox, K. (1999). What factors support or prevent teaches from using ICT in their classroom? Paper presented at the British Education Research Association Annual Conference. Retrieved August 2, 2008 from http://leeds.ac.uk/educol/documents 100001304.htm

Cuban, L., Kirkpatrick, H., \& Peck, C. (2001). High access and low use of technologies in high school classrooms: explaining an apparent paradox. American Educational Research Journal, 38(4), 813-834

Dawes, L., (2001). What stops teachers using new technology? In M. Leask (Ed.), Issues in Teaching using ICT. London: Routledge.

Empirica (2006). Benchmarking access and use of ICT in European schools 2006: final report from Head Teacher and Classroom Teacher Survey in 27 European countries. Germany: European Commission. p44

Gomes, C. (2005). Integration of ICT in science teaching: A study performed in Azore, Portugal. Recent Research Development in Learning Technology. pp1-6

Jhurree, V. (2005).Technology integration in education in developing countries: Guidelines to policy makers. International Education Journal, pp467-483.

Hew, K., \& Brush, T. (2007). Integrating Technology into K-12 Teaching and Learning: Current knowledge gaps and recommendations for future research. Educational Technology Research, 55(3), 223-252.

Korte, W.B., \& Husing, T. (2007). Benchmarking access and use of ICT in European schools 2006: Results from Head Teacher and A Classroom Teacher Surveys in 27 European countries. e-Learning Paper, 2(1), 1-6

Kozma, R. (2005). National Policies That Connect ICT-Based Education Reform to Economic and Social Development, Human Technology, 1(2), 117-156.

Lei, J., \& Zhao, Y. (2007). Computer uses and student achievement: A longitudinal study. Computers and Education, 49, $284-296$.

Newhouse CP (2002). Literature Review: The Impact of ICT on Learning and Teaching. From http://www.det. (Retrieved on August 12 , 2012).

Newhouse, CP, \& Clarkson, BD. (2008). Using Learning Environment Attributes to Evaluate the Impact of ICT on Learning in Schools. Research and Practice in Technology Enhanced Learning. 3 (2): pp. 139-158

Makgato, M. (2012). Status of teachers' use of educational technology: a case of some schools in South African semi-urban locations. International Proceedings of Economics Development and Research - Business and Economics Research V47. IACSIT PRESS, ISBN: 978-981-07-3595-1, ISSN: 2010-4626, full text available online at http://www.ipedr.com. 
Mayisela, T. (2014). Assessing How E-learning Implementation has Enhanced the Lecturers' Teaching Practices at a South African University. International Journal of Educational Science. 6(1): pp. 117-214.

Mumtaz, S. (2006). Factors affecting teachers' use of information and communications technology: a review of the literature. Journal of Information Technology for Teacher Education, 9: 3, 319-342.

Ozden, M (2007). Problems with Science and Technology Education in Turkey .Eurasia Journal of Mathematics, Science \& Technology Education. 3(2) 157-161

Pelgrum, W.J. (2001). Obstacles to the integration ICT in Education: Results from a Worldwide Educational Assessment. Computers in Education 37(2), 163-178.

Ross, J. (2000). An Exploratory analysis of Student Achievement Comparing a Web-Based and a Conventional Course Learning Environment. Report for the Office of Learning Technology. University of Calgary.

Schoepp, K. (2005). Barriers to technology integration in a technology rich environment. Learning and Teaching in Higher Education: Gulf Perspectives, 2(1), pp. 1-24.

Sicilia, C. (2005). The Challenges and Benefits to Teachers' Practices in Constructivist Learning Environments by Technology. Unpublished Master's thesis. McGill University, Montreal.

Shaikh, Z., A., \& Khoja, S. A. (2011). Role of ICT in shaping the future of Pakistani higher education system. The Turkish Online Journal of Educational Technology, 10(1): pp.149-161.

Song, H-D \& Kong, T. (2012). Evaluating the impacts of ICT use: a multi-level analysis with hierarchical linear modelling. 11(4): pp. 132149.

Toprakci, E. (2006). Obstacles at integration of schools into information and communication technologies by taking into consideration the opinion of the teachers and principals of primary and secondary schools in Turkey. Journal of Instructional Science and Technology (e-JIST), 9(1):pp. 1-16

Yusuf, M. O., \& Afolabi, A. O. (2010). Effects of computer assisted instruction (cai) on secondary school students' performance in biology. The Turkish Online Journal of Educational Technology, 9(1): 62-69.

Wozney, L. , Venkatesh, V \& Abrami, P.C. (2006). Implementing computer technologies: teachers perceptions and practices . Journal of Technology and Teacher Education. 14(1): pp 173-207) 